\title{
Possible Clues to a Functional Cure for HIV Infection
}

\author{
Yu Lai \\ Department of Microbiology and Immunology, Chengdu University of Traditional Chinese Medicine, \\ Chengdu, China
}

Sir,

Combination antiretroviral therapy (ART) has substantially increased the life expectancy of people living with the human immunodeficiency virus type 1 (HIV-1), but cannot cure the infection due to the persistent reservoirs that preclude virus eradication. Accordingly, a functional cure that permits treatment discontinuation seems to be a more realizable short-term goal. Researchers recently identified 14 HIV patients who had initiated ART during the primary infection and subsequently controlled viral replication for a median of 7.4 years after the interruption of a prolonged therapy [1]. Moreover, these socalled posttreatment controllers in that cohort had very weak HIV-specific CD8+ $\mathrm{T}$-cell responses, severe primary infections and no favorable genetic background when compared with HIV controllers who spontaneously controlled HIV replication in the absence of medication [1]. These findings reveal that a very early initiation of therapy may prevent the establishment of HIV reservoirs and enable some individuals to achieve a functional cure. Nevertheless, early therapeutic intervention is not always feasible, especially for patients with chronic HIV-1 infection, and other approaches are being explored.

The HIV-1 enters target cells through the binding of gp120 to a CD4 receptor and then to a coreceptor, CCR5 or CXCR4. Early in the HIV epidemic, it was recognized that some people, now known as HIV-exposed seronegative individuals, remained uninfected despite having been exposed to HIV-1 on many occasions including unprotected sex, intravenous drug use, birth to an HIV-infected mother, transfusion of blood and blood products, and occupational exposure to HIV [2]. The definite mechanism underlying the natural protection is a 32-base pair deletion in the CCR5 gene $(C C R 5 \Delta 32)$ encoding a nonfunctional receptor. Homozygosity for the polymorphism confers profound resistance to acquisition with CCR5-tropic but not CXCR4-tropic strains, and the heterozygous state is also associated with delayed progression to AIDS $[3,4]$. This knowledge has important implications for developing new HIV-1 therapies that utilize the homozygous CCR5 $\triangle 32$ genetic defect. Following myeloablation, Hütter et al. [5] transplanted hematopoietic stem cells (HSCs) from a HLA-matched donor who was homozygous for CCR5 $\triangle 32$ in an acute myeloid leukemia patient (the 'Berlin patient'). Despite ART administered until the day before the hematopoietic stem cell transplantation (HSCT), viral replication has continued to be absent for more than 6 years.

The Berlin patient so far represents the sole case of an HIV cure. In fact, there were other patients receiving a graft from donors who had been screened for CCR5 $\triangle 32$ homozygosity. Unfortunately, none of the recipients survived for a long time [6-8]. These undesirable results can be explained in part by the grafts not engendering a very low viral reservoir that failed to allow HIV reseeding in the replaced immune system. In comparison, the Berlin patient experienced fully ablative conditioning with a potentially lethal regimen. And, owing to a relapse of the acute myeloid leukemia, a second transplantation employing stem cells from the same donor was accomplished approximately 1 year after the first transplant, which required exposure to myeloablative therapy again, including a single dose of whole-body irradiation. It is speculated that the myeloablative preparative regimen combined with the graft-versus-host disease experienced by the patient may have been responsible for the cure by decreasing the numbers of susceptible activated CD4+ T cells and by eliminating latently infected cells. This would account for the fact that HIV did not rebound in the body of the Berlin patient after ART interruption. Additionally, a disappointing study reported that HIV recurred in 2 patients (the 'Boston patients'), who had undetectable HIV-1 RNA, proviral HIV-1 DNA and viral outgrowth in their plasma, peripheral blood mononuclear cells and gut-associated lymphoid tissue years after a reduced-intensity conditioning allogeneic HSCT with CCR5 wild-type donor cells [9]. They differed from the Berlin patient,

\section{KARGER 125}

C 2015 S. Karger AG, Base

0300-5526/15/0583-0181\$39.50/0
Yu Lai

Department of Microbiology and Immunology Chengdu University of Traditional Chinese Medicine 37 shi-er-qiao road, Chengdu 610075 (China)

E-Mail archimedean@ rocketmail.com 
who achieved durable HIV-1 remission after 2 myeloablative HSCTs with resistant donor cells. Importantly, the allogeneic HSCT contributed to variable periods of antiretroviral-free HIV-1 remission, but viral reemergence took place despite a minimum $3-\log _{10}$ reduction in reservoir size. Considering the fact that the pretransplantation conditioning usually does not lead to the complete elimination of HIV [10-12], one possible explanation for the surprising result of Hütter's group [5] may be that the reconstituted immune system with CCR5-deficient cells persistently suppresses the reactivation of viral replication from HIV reservoirs which have been greatly reduced by previous ablative regimens and ART. As a unique case, the Berlin patient should be considered a proofof-concept, which has fueled the possibility of a cure for HIV.

The progress, discussed above, supports a potential combination strategy allowing CCR5 to be effectively and permanently disrupted by the methods for genome engineering [13] in long-lived, multilineage autologous HSCs isolated from HIV-1-positive subjects or differentiated from induced pluripotent stem cells (iPSCs) [14]. After a prolonged ART together with innovative approaches to minimize the size of latent HIV reservoirs [15], these CCR5 $5^{-/}$cells would be directly infused into a human body that has undergone a mild myeloablation to facilitate engraftment with minimal associated toxicity. Following the cessation of the ART, the viral rebound from an extremely low viral reservoir would be hampered by the resultant immune system consisting of CCR5 $5^{-/}$ and $\mathrm{CCR}^{+/+} \mathrm{CD} 4+$ cells.

Given the possibility that HSCs may serve as long-lived cellular reservoirs of latent HIV-1 [16], the potential risk involved with the transplantation of gene-modified autologous CCR5 ${ }^{-/-}$HSCs derived from an HIV-infected person should be considered. Fortunately, there is convincing evidence that direct reprogramming of somatic cells with POU5F1, SOX2, NANOG, and LIN28 allows the generation of patient-specific iPSCs which can successfully differentiate through CD34+ primitive blood cells into all types of hematopoietic colonies [17], thus providing an unprecedented opportunity to produce virus-free hematopoietic cells. However, the production of HSCs with robust and sustained multilineage engraftment still remains elusive, mainly due to the dysfunction of
iPSC-derived hematopoietic cells and the low efficiency of current protocols for producing blood lineages [14]. Nevertheless, studies have shown that hematopoietic differentiation could be realized in vivo during teratoma formation from human iPSCs, giving hope to yielding eligible HSCs with authentic engraftment potential $[18,19]$. In the past years, ongoing strategies have been attempted to produce HIV resistance by disrupting the CCR 5 and/or CXCR4 gene in iPSCs, autologous CD34+ cells and CD4+ T-cells [20-24]. There are 3 main types of nucleases currently developed for genome modifications, including zinc finger nucleases (ZFNs), transcription activator-like effector nucleases, and clustered regularly interspaced short palindromic repeats [13]. These nucleases mediate double-strand breaks in the genome and significantly improve genome targeting efficiency by the host's cellular DNA repair machinery, for instance the nonhomologous end joining [13]. Using engineered ZFNs, Holt et al. [20] achieved a mean disruption frequency of $17 \%$ of the total alleles in the HSC population. These ZFN-treated HSCs retained the ability to engraft immunodeficient mice and rebuild the immune system. Upon challenge with a CCR5-tropic strain, a rapid selection for human cells that were CCR5-negative was observed, and these animals had lower viral loads and higher CD4+ T-cell levels than those receiving untreated HSCs. These observations demonstrated that the genetic alteration of only a minority of human HSCs was sufficient to create a permanent supply of HIV-resistant progeny, able to replace immune cells destroyed by HIV-1, and they also suggest that an autologous transplant of $\mathrm{CCR}^{-/-} \mathrm{CD} 34+$ cells administered under nonmyeloablative conditioning may be effective to induce immune reconstitution and the long-term control of HIV replication in the absence of antiretroviral medication. The safety and feasibility of CCR5-targeted ZFNs have been evaluated in a phase I clinical trial, which enrolled 12 patients [23]. These patients had a chronic aviremic HIV infection while taking highly active ART. They were infused with a single dose of 10 billion autologous CD4+ $\mathrm{T}$ cells, $11-28 \%$ of which were genetically modified at the CCR5 gene locus by ZFNs. It was found that the genetically manipulated cells persisted in vivo with a half-life of nearly 1 year. Although viremia recurred in all persons when the antiretrovi- ral treatment was interrupted, the rate of decline was significantly greater for the median unmodified CD4+ T cells than for the CCR5-altered CD4+ T cells, and 1 of 4 participants who could be evaluated had an undetectable HIV RNA before the reinstitution of the highly active ART. Interestingly, the blood level of HIV DNA decreased in most patients. The results show that CCR5-modified autologous CD4+ Tcell infusions are safe and associated with an acceptable adverse event profile within the limits of this study. In addition, recent research seamlessly reproduced iPSCs homozygous for the naturally occurring CCR5 $\triangle 32$ mutation without leaving any residual sequences at an average of $14 \%$ and $33 \%$ through genome editing of wild-type iPSCs, using a combination of transcription activator-like effector nucleases or RNA-guided CRISPR-Cas9 together with piggyBac technology, respectively [24]. Remarkably, off-target effects, which raise concerns about genotoxicity, by engineered nucleases were not detected in this study.

It should be noted that HSCT with $C C R 5 \Delta 32 / \triangle 32$ mutation might induce a shift of HIV tropism from CCR5 to CXCR4. In a rare case, a CXCR4-tropic variant rebounded rapidly after transplantation from a donor who was homozygous for the CCR5 $\triangle 32$ allele [7]. However, it has remained unclear whether the coreceptor switch in this patient occurred before the allogeneic HSCT or after the transplantation [8]. More importantly, the Berlin patient harbored CXCR4-utilizing viruses before the HSCT, yet did not experience a tropism switch and, instead, successfully controlled HIV-1 infection for a long time [5]. Consistently, an emergence of a CXCR4using virus is not generally found in patients treated with CCR5 inhibitors, unless CXCR4-tropic viruses were present before the therapy, and it has been proposed that switching to the use of the CXCR4 coreceptor is rare because of the features of transitional variants, such as decreased fitness and increased sensitivity to CCR5 antagonists [25]. For these reasons, it should be determined whether the strategy presented here could also promise a functional cure for HIV sufferers infected with CXCR4utilizing viruses.

\section{Disclosure Statement}

The authors have no conflicts of interest to disclose. 


\section{References}

-1 Saez-Cirion A, Bacchus C, Hocqueloux L, Avettand-Fenoel V, Girault I, Lecuroux C, Potard V, Versmisse P, Melard A, Prazuck T, Descours B, Guergnon J, Viard JP, Boufassa F, Lambotte O, Goujard C, Meyer L, Costagliola D, Venet A, Pancino G, Autran B, Rouzioux C: Post-treatment HIV-1 controllers with a long-term virological remission after the interruption of early initiated antiretroviral therapy ANRS VISCONTI Study. PLoS Pathog 2013;9:e1003211.

-2 Shearer GM, Clerici M: Protective immunity against HIV infection: has nature done the experiment for us? Immunol Today 1996;17: 21-24.

3 Samson M, Libert F, Doranz BJ, Rucker J, Liesnard C, Farber CM, Saragosti S, Lapoumeroulie C, Cognaux J, Forceille C, Muyldermans G, Verhofstede C, Burtonboy G, Georges M, Imai T, Rana S, Yi Y, Smyth RJ, Collman RG, Doms RW, Vassart G, Parmentier M: Resistance to HIV-1 infection in Caucasian individuals bearing mutant alleles of the CCR- 5 chemokine receptor gene. Nature 1996;382:722-725.

4 Dean M, Carrington M, Winkler C, Huttley GA, Smith MW, Allikmets R, Goedert JJ, Buchbinder SP, Vittinghoff E, Gomperts E, Donfield S, Vlahov D, Kaslow R, Saah A, Rinaldo C, Detels R, O’Brien SJ: Genetic restriction of HIV-1 infection and progression to AIDS by a deletion allele of the CKR 5 structural gene. Hemophilia Growth and Development Study, Multicenter AIDS Cohort Study, Multicenter Hemophilia Cohort Study, San Francisco City Cohort, ALIVE Study. Science 1996;273:1856-1862.

5 Hütter G, Nowak D, Mossner M, Ganepola S, Mussig A, Allers K, Schneider T, Hofmann J, Kucherer C, Blau O, Blau IW, Hofmann WK, Thiel E: Long-term control of HIV by CCR5 Delta32/Delta32 stem-cell transplantation. N Engl J Med 2009;360:692-698.

6 6 Hütter G: More on shift of HIV tropism in stem-cell transplantation with CCR5 delta32/ delta32 mutation. N Engl J Med 2014;371: 2437-2438.

7 Kordelas L, Verheyen J, Beelen DW, Horn PA, Heinold A, Kaiser R, Trenschel R, Schadendorf D, Dittmer U, Esser S: Shift of HIV tropism in stem-cell transplantation with CCR5 Delta32 mutation. N Engl J Med 2014;371:880-882.
8 Verheyen J, Esser S, Kordelas L: More on shift of HIV tropism in stem-cell transplantation with CCR5 delta32/delta32 mutation. N Engl J Med 2014;371:2438.

-9 Henrich TJ, Hanhauser E, Marty FM, Sirignano MN, Keating S, Lee TH, Robles YP, Davis BT, Li JZ, Heisey A, Hill AL, Busch MP, Armand P, Soiffer RJ, Altfeld M, Kuritzkes DR: Antiretroviral-free HIV-1 remission and viral rebound after allogeneic stem cell transplantation: report of 2 cases. Ann Intern Med 2014;161:319-327.

10 Avettand-Fenoel V, Mahlaoui N, Chaix ML, Milliancourt C, Burgard M, Cavazzana-Calvo $\mathrm{M}$, Rouzioux C, Blanche S: Failure of bone marrow transplantation to eradicate HIV reservoir despite efficient HAART. AIDS 2007; 21:776-777.

11 Polizzotto MN, Skinner M, Cole-Sinclair MF, Opat SS, Spencer A, Avery S: Allo-SCT for hematological malignancies in the setting of HIV. Bone Marrow Transplant 2010;45:584586.

12 Cillo AR, Krishnan A, Mitsuyasu RT, McMahon DK, Li S, Rossi JJ, Zaia JA, Mellors JW: Plasma viremia and cellular HIV-1 DNA persist despite autologous hematopoietic stem cell transplantation for HIV-related lymphoma. J Acquir Immune Defic Syndr 2013;63: 438-441.

13 Drake MJ, Bates P: Application of gene-editing technologies to HIV-1. Curr Opin HIV AIDS 2015;10:123-127.

14 Liu S, Xu Y, Zhou Z, Feng B, Huang H: Progress and challenges in generating functional hematopoietic stem/progenitor cells from human pluripotent stem cells. Cytotherapy 2015;17:344-358.

15 Dahabieh MS, Battivelli E, Verdin E: Understanding HIV latency: the road to an HIV cure. Annu Rev Med 2015;66:407-421.

-16 Carter CC, McNamara LA, Onafuwa-Nuga A, Shackleton M, Riddell Jt, Bixby D, Savona MR, Morrison SJ, Collins KL: HIV-1 utilizes the CXCR4 chemokine receptor to infect multipotent hematopoietic stem and progenitor cells. Cell Host Microbe 2011;9:223-234.

17 Choi KD, Yu J, Smuga-Otto K, Salvagiotto G, Rehrauer W, Vodyanik M, Thomson J, Slukvin I: Hematopoietic and endothelial differentiation of human induced pluripotent stem cells. Stem Cells 2009;27:559-567.
18 Amabile G, Welner RS, Nombela-Arrieta C, D'Alise AM, Di Ruscio A, Ebralidze AK, Kraytsberg Y, Ye M, Kocher O, Neuberg DS, Khrapko K, Silberstein LE, Tenen DG: In vivo generation of transplantable human hematopoietic cells from induced pluripotent stem cells. Blood 2013;121:1255-1264.

19 Suzuki N, Yamazaki S, Yamaguchi T, Okabe M, Masaki H, Takaki S, Otsu M, Nakauchi H: Generation of engraftable hematopoietic stem cells from induced pluripotent stem cells by way of teratoma formation. Mol Ther 2013;21:1424-1431.

20 Holt N, Wang J, Kim K, Friedman G, Wang X, Taupin V, Crooks GM, Kohn DB, Gregory PD, Holmes MC, Cannon PM: Human hematopoietic stem/progenitor cells modified by zinc-finger nucleases targeted to CCR5 control HIV-1 in vivo. Nat Biotechnol 2010;28: 839-847.

21 Wilen CB, Wang J, Tilton JC, Miller JC, Kim KA, Rebar EJ, Sherrill-Mix SA, Patro SC, Secreto AJ, Jordan AP, Lee G, Kahn J, Aye PP, Bunnell BA, Lackner AA, Hoxie JA, DanetDesnoyers GA, Bushman FD, Riley JL, Gregory PD, June $\mathrm{CH}$, Holmes MC, Doms RW: Engineering HIV-resistant human CD4+ T cells with CXCR4-specific zinc-finger nucleases. PLoS Pathog 2011;7:e1002020.

22 Didigu CA, Wilen CB, Wang J, Duong J, Secreto AJ, Danet-Desnoyers GA, Riley JL, Gregory PD, June CH, Holmes MC, Doms RW: Simultaneous zinc-finger nuclease editing of the HIV coreceptors ccr5 and cxcr4 protects CD4+ T cells from HIV-1 infection. Blood 2014;123:61-69.

23 Tebas P, Stein D, Tang WW, Frank I, Wang SQ, Lee G, Spratt SK, Surosky RT, Giedlin MA, Nichol G, Holmes MC, Gregory PD, Ando DG, Kalos M, Collman RG, BinderScholl G, Plesa G, Hwang WT, Levine BL, June $\mathrm{CH}$ : Gene editing of CCR5 in autologous CD4 T cells of persons infected with HIV. N Engl J Med 2014;370:901-910.

24 Ye L, Wang J, Beyer AI, Teque F, Cradick TJ, Qi Z, Chang JC, Bao G, Muench MO, Yu J, Levy JA, Kan YW: Seamless modification of wild-type induced pluripotent stem cells to the natural CCR5Delta32 mutation confers resistance to HIV infection. Proc Natl Acad Sci USA 2014;111:9591-9596.

25 Gilliam BL, Riedel DJ, Redfield RR: Clinical use of CCR5 inhibitors in HIV and beyond. J Transl Med 2011;9(suppl 1):S9. 